\title{
Health-related quality of life in informal settlements in Kermanshah, Islamic Republic of Iran: role of poverty and perception of family socioeconomic status
}

Seyed Ramin Ghasemi, ${ }^{1}$ Alireza Zangeneh, ${ }^{1}$ Nader Rajabi-Gilan, ${ }^{1}$ Sohyla Reshadat, ${ }^{1}$ Shahram Saeidi ${ }^{1}$ and Arash Ziapour ${ }^{1}$

${ }^{1}$ Social Development and Health Promotion Research Center, Health Institute, Kermanshah University of Medical Sciences, Kermanshah, Islamic Republic of Iran (Correspondence to: Alireza Zangeneh: ali.zangeneh88@gmail.com).

\begin{abstract}
Background: Quality of life is an important indicator for measuring health status, and information on quality of life of different groups in society can be used to assess the effect of interventions on health.

Aims: This study aimed to assess the relationship between urban poverty and perception of family socioeconomic status, and health-related quality of life in residents of informal settlements.

Methods: A cross-sectional study was conducted among 432 residents of two neighbourhoods of informal settlements in Kermanshah in 2015. To measure poverty, the 16 indicators of 2011 Iranian census were used. The neighbourhoods were classified into three groups: high poverty (9.3\%), middle poverty $(49.2 \%)$ and low poverty (41.5\%) levels. Health-related quality of life was assessed with the SF-36 questionnaire. The Pearson correlation coefficient was calculated and regression and ANOVA analyses were done.

Results: There were no statistically significant differences between the SF-36 scores for the three poverty levels, and no relationship between poverty and the health-related quality of life subscales $(P>0.05)$. A significant positive correlation was found between perception of family socioeconomic status and health-related quality of life $(P<0.05)$. In regression analysis, having a chronic illness, perception of family socioeconomic status, age and sex predicted the physical health domain of the SF-36, whereas perception of family socioeconomic status and having a chronic illness predicted the mental health domain.
\end{abstract}

Conclusions: Subjective perception of family socioeconomic status can explain differences in health-related quality of life of low-income people.

Keywords: quality of life, health status, urban poverty, Iran

Citation: Ghasemi SR; Zangeneh A; Rajabi-Gilan N; Reshadat S; SaeidiS; Ziapour A. Health-related quality of life in informal settlements in Kermanshah, Islamic Republic of Iran: role of poverty and perception of family socioeconomic status. East Mediterr Health J. 2019;25(11):775-783. https://doi. org/10.26719/emhj.19.013

Received: 15/08/16; accepted: 06/12/17

Copyright (c) World Health Organization (WHO) 2019. Some rights reserved. This work is available under the CC BY-NC-SA 3.0 IGO license https:// creativecommons.org/licenses/by-nc-sa/3.o/igo

\section{Introduction}

Over the past few decades, promotion of quality of life, one of the main goals of human development, has affected policy-making in many countries $(1-3)$. As well as the increasing importance of social goals and formulating them into development plans, sociological and human attitudes about quality of life have gradually found their way into planning and policy-making for health care systems. As a general term, quality of life is a concept to show how human needs are fulfilled and a benchmark for understanding the satisfaction or dissatisfaction of individuals and groups with the different aspects of their lives $(4,5)$. The World Health Organization (WHO) defines quality of life as "the individuals' perception of their position in life in the context of the culture and value systems in which they live and in relation to their goals, expectations, standards and concerns" (6).

Quality of life is one of the main indicators for measuring health status (3); therefore, information on the quality of life of different groups in society can be used to assess the effect of interventions and implemented programmes on health (7).

It is predicted that by 2030 the urban population will be larger than the rural population in developing areas of the world (8). One of the outcomes of this population mobility and growing urbanization is increasing urban poverty (9). The main manifestation of urban poverty is informal settlements (10). According to estimates of the United Nations, more than one billion people, about $14 \%$ of the world's population, live in slums and this could double by the year of $2030(11,12)$. In the Islamic Republic of Iran, as with other middle-income countries, rapid urbanization has led to the expansion of informal settlements in the areas surrounding big cities (13). Kermanshah city, the capital of Kermanshah Province in the west of country, has a population of 946651 (2016 data) (14), most of whom are of Kurdish ethnicity. The province is faced with the problem of informal settlements, especially in Kermanshah city (15).

Inequality in access to health promotion opportunities and increasing health risks are the main health consequences of living in informal settlements (16). Apart 
from the environmental and physical problems of these areas, people living in informal settlements are poor and deprived (17). Both the unfavourable environment and the poverty can have a destructive effect on the quality of life.

Although, previous studies have shown the negative effect of poverty on health (18-20), few studies have been conducted on the relationship between poverty and healthrelated quality of life in the Islamic Republic of Iran (21). In addition, most studies have calculated income poverty and compared poor groups with non-poor groups. However, in the present study, the sample was drawn from poor areas (informal settlements) and participants were grouped into poverty levels. In addition, the capability approach was used to measure poverty using social, cultural, economic and physical indicators. The capability approach considers that freedom to achieve well-being is a matter of what people are able to do and to be, and thus the kind of life they are effectively able to lead $(22,23)$. The aim of our study was to explore the relationship between urban poverty and perception of family socioeconomic status, and health-related quality of life in people living in informal settlements in Kermanshah city.

\section{Methods}

\section{Study design}

This was a cross-sectional study carried out in 2015 .

\section{Study population and sample selection}

The study population was residents of 13 informal settlements in Kermanshah city (15). Using multistage stratified cluster sampling, two neighbourhoods (Dowlatabad and Jafarabad) were selected because $70 \%$ of people living in the informal settlements of Kermanshah live there (Figure 1) (14,15).

The selected neighbourhoods were divided into the statistical blocks used by the 2011 population and housing census, and the poverty status was assessed using 16 indicators of the census from the Statistical Centre of Iran (Table 1). We examined poverty through the social justice $(24,25)$ and capability approach. Therefore, to evaluate the poverty status across the statistical blocks, the economic, social, cultural and physical indicators (Table 1) used in other studies $(17,26)$ were considered the poverty index. Using cluster analysis in Arc/GIS software, the poverty index was evaluated and the statistical blocks of the two selected neighbourhoods were classified into three groups: high poverty level (most deprived group), middle poverty level and low poverty level.

The results of statistical data analysis for measurement of poverty showed that from a total of 453 blocks, 42 blocks (9.72\%) with 5160 residents, 223 blocks (49.23\%) with 35 104 residents and 118 blocks (41.50\%) with 27927 residents were classified as high, middle and low poverty levels respectively (Figure 1). Threeblocks were selected randomly from each poverty level in the two neighbourhoods ( 18 blocks in total). After this, study samples were selected

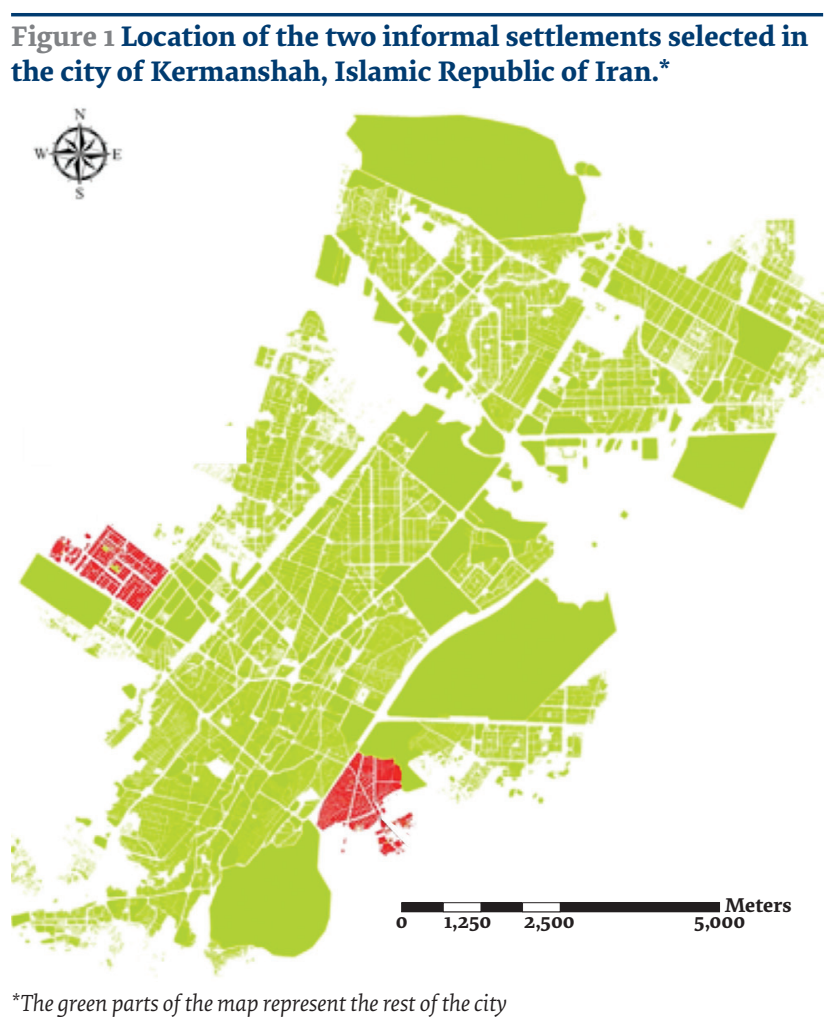

from the 18 blocks using a multistage stratified cluster sampling method.

\section{Data collection}

Trained investigators visited the selected households. At each house, one of the residents (over 15 years) was selected randomly. After the investigator explained the purpose of the study, she/he completed the questionnaire. The questionnaire was filled by the investigator for illiterate respondents.

\section{Perception of family socioeconomic status}

This was evaluated using a subjective social status scale (27), which is a measure designed to capture an individual's subjective evaluation of her/his social status relative to society (28). In an easy pictorial format, it presents 10 rungs, a "social ladder", and asks individuals to place an " $\mathrm{X}$ " on the rung on which they feel they stand. The respondent's selection is based on her/his family education level, employment status and wealth. The ladder translates to a 10-point continuum (1-10) where 1 represents the worst socioeconomic status and 10 the best (best education, wealth and employment status).

\section{Health-related quality of life tool}

The short form health survey (SF-36) was used to measure health-related QOL. It has two main domains (physical and mental/emotional health) and eight subscales [physical functioning (limit or no limit in performing all types of physical activity), role physical (problem or no problem with work or other daily activities as a result of physical health), bodily pain (very severe and extremely limiting pain or no pain or limitations because of pain), general health (believes personal health is poor or excellent), vitality (feels tired and worn out all of the time or not at 


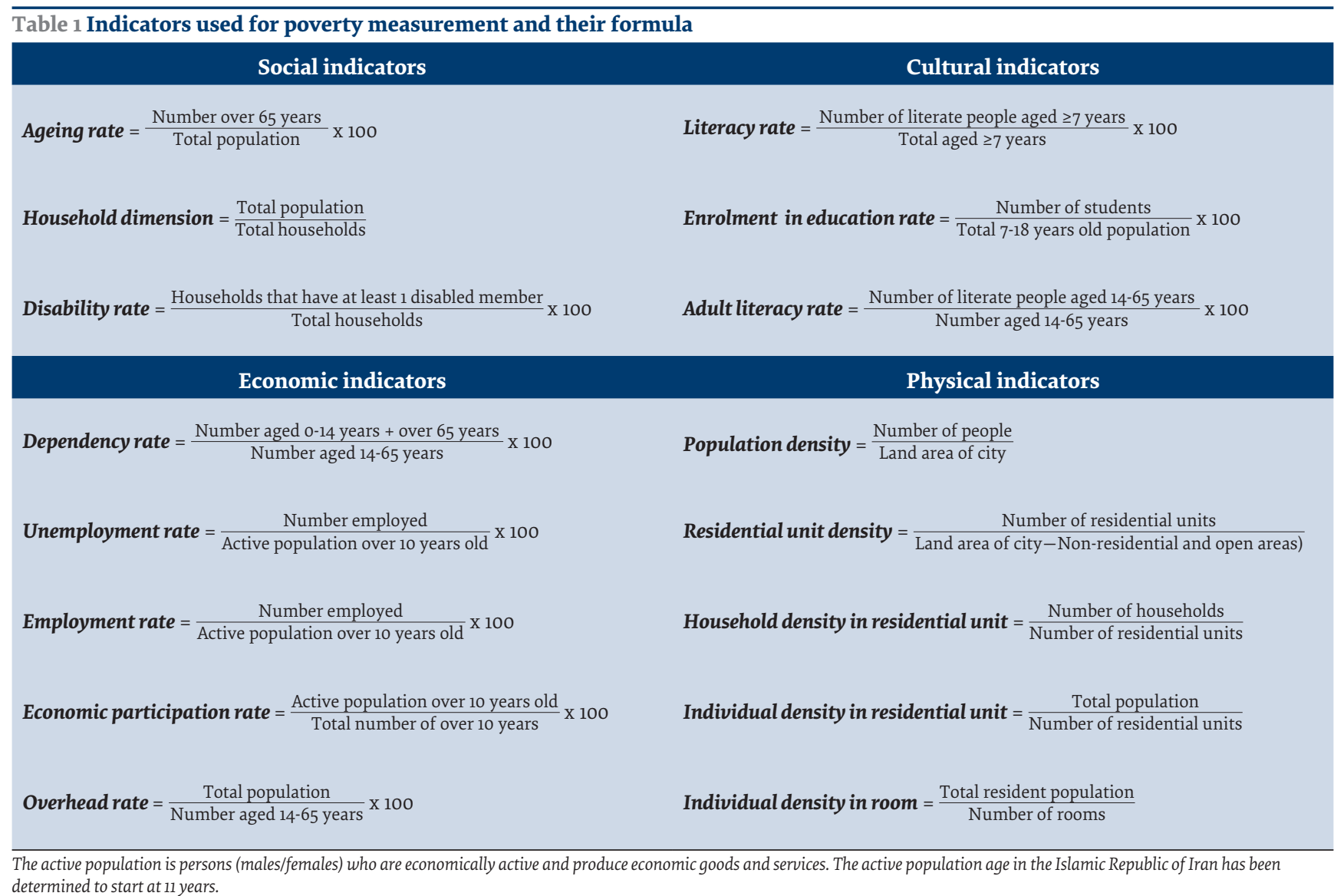

all), social functioning (extreme and frequent interference with normal social activities because of physical and emotional problems or normal performance), role emotional (problem or no problem with work or other daily activities as a result of emotional problems) and mental health (feelings of nervousness and depression all of the time or feels peaceful and happy) (29).

SF-36 is a valid and reliable questionnaire. The Cronbach alpha for SF-36 subscales are between 0.69 ando.93 (29). In addition, Montazeri and colleagues showed that the Farsi version of the SF-36 has acceptable validity in the Iranian population: Cronbach alphas for the Farsi version of SF36 subscales were between 0.77 to 0.9 (30). The domains and subscales of the SF-36 questionnaire are scored from $0-100$ where zero and 100 scores indicate the worst and best quality of life status respectively.

\section{Demographic variables}

Data on age, sex, marital status, education and neighbourhood were collected. Also respondents answered a question about whether or not they had any chronic illnesses.

\section{Statistical analysis}

Data were analysed using Arc/GIS and SPSS, version 18 software. The level of significance was set at $P<0.05$. The Pearson correlation coefficient was calculated to assess the linear relationship between age and perception of family socioeconomic status, and quality of life. ANOVA was used to examine the relationship between marital status and educational level, and quality of life. The independent t-test was used to analyse the relationship between sex and neighbourhood, and quality of life. Linear regression analysis using the backward step method was done to determine the adjusted associations of all variables with quality of life.

\section{Ethical considerations}

The study was approved by the review board of the Kermanshah University of Medical Sciences (project code: 93493). All procedures performed involving human participants were done in accordance with the ethical standards of the institutional research committee and the 1964 Helsinki declaration and its later amendments. Informed consent was obtained verbally from all participants in the study.

\section{Results}

A total of 450 people (over 15 years old) were selected and 432 filled the questionnaires completely (response rate: $96 \%$ ). Of the 432 respondents, $54.2 \%$ were female. The mean age of the respondents was 29.93 (SD 11.34) years, and ranged from 15 to 72 years. Most of the participants were married (56.7\%). Almost half of the respondents had not completed high school (48.1\%), 31.1\% had a high-school diploma and $20.80 \%$ had a university degree. Significant differences were found between the physical health domain of SF-36 and marital status, educational level and neighbourhood $(P<0.05)$ (Table 2).

The results for the eight subscales of the SF- 36 health- 


\begin{tabular}{|c|c|c|c|c|c|}
\hline \multirow[t]{2}{*}{ Characteristic } & \multirow[t]{2}{*}{ Males } & \multirow[t]{2}{*}{ Females } & \multirow[t]{2}{*}{ Total } & \multicolumn{2}{|c|}{ HRQoL domains } \\
\hline & & & & Physical health & Mental health \\
\hline & No. (\%) & No. (\%) & No. $(\%)$ & Mean (SD) & Mean (SD) \\
\hline Number & $198(45.8)$ & $234(54.2)$ & $432(100)$ & - & - \\
\hline Age [mean (SD)] & $30.87(12.18)$ & $29.14(10.54)$ & $29.93(11.34)$ & - & - \\
\hline \multicolumn{6}{|l|}{ Marital status } \\
\hline Married & $109(55.6)$ & $133(57.6)$ & $242(56.7)$ & $62.31(19.83)$ & $55.44(19.72)$ \\
\hline Single & $82(41.8)$ & $78(33.8)$ & $160(37.5)$ & $68.38(18.82)$ & $60.28(20.74)$ \\
\hline Divorced/widowed & $5(2.6)$ & $20(8.6)$ & $25(5.8)$ & $53.05(19.46)$ & $54.31(20.46)$ \\
\hline$P$-value & & & & $<0.001$ & 0.048 \\
\hline \multicolumn{6}{|l|}{ Educational level } \\
\hline Illiterate & $13(6.7)$ & $18(7.7)$ & $31(7.2)$ & $49.48(22.06)$ & $49.81(19.07)$ \\
\hline $\begin{array}{l}<\text { High-school } \\
\text { diploma }\end{array}$ & $72(36.9)$ & $103(44.2)$ & $175(40.9)$ & $61.26(19.32)$ & $56.01(19.43)$ \\
\hline High-school diploma & $58(29.7)$ & $75(32.2)$ & $133(31.1)$ & $67.68(18.44)$ & $59.40(20.59)$ \\
\hline University degree & $52(26.7)$ & $37(15.9)$ & $89(20.8)$ & $68.76(18.90)$ & $57.70(20.89)$ \\
\hline$P$-value & & & & $<0.001$ & 0.095 \\
\hline \multicolumn{6}{|l|}{ Neighbourhood } \\
\hline Dowlatabad & $100(50.5)$ & $104(44.4)$ & $204(47.2)$ & $66.80(19.19)$ & $56.95(20.17)$ \\
\hline Jafarabad & $98(49.5)$ & $130(55.6)$ & $228(52.8)$ & $61.63(20.02)$ & $57.26(20.21)$ \\
\hline$P$-value & & & & 0.007 & 0.872 \\
\hline
\end{tabular}

$\mathrm{HRQOL}=$ health-related quality of life, $S \mathrm{D}=$ standard deviation.

related quality of life are given in Table 3. The mean scores of the physical functioning (76.23) and role emotional(49.61) subscales were the highest and lowest respectively. SF-36 subscale scores was generally higher in males, but this was only statistically significant for the bodily pain subscale $(P=0.026)$ (Table 3).

There was a negative correlation between age and all the subscales of the physical health domain of SF-36 $(P<0.05)$; older people had poorer physical health-related quality of life. However, no correlation was found between age and subscales of the mental health domain, except for vitality $(P=0.002)$.

The results of ANOVA showed no statistically significant differences between the SF-36 scores of the three poverty levels $(P>0.05)$ (Table 4$)$.
The mean (standard deviation) scores of individuals' perceptions of their family socioeconomic status were 3.90 (SD 1.88). In addition, the mean scores for the low poverty level, middle poverty level and high poverty level groups were 4.12 (SD 1.84), 3.90 (SD 1.88) and 3.52 (SD 1.84) respectively. The results suggest that members of the high poverty level group perceived their socioeconomic status level significantly more positively than the other two groups $(P=0.023)$.

There was a positive correlation between perception of family socioeconomic status and SF-36 subscales $(P<0.05)$. The highest and the lowest correlation coefficients were between perception of family socioeconomic status and vitality subscale $(r=0.376)$ and physical functioning $(r=0.095)$ respectively.

\begin{tabular}{|c|c|c|c|c|c|}
\hline Main domains & Subscales & Total score & Females & Males & P-value \\
\hline \multirow{3}{*}{ Physical health } & & Mean (SD) & Mean (SD) & Mean (SD) & \\
\hline & Physical functioning & $76.23(24.69)$ & $74.32(24.67)$ & 78.48 (24.60) & 0.081 \\
\hline & Role physical & $58.34(36.83)$ & $57.11(36.50)$ & $59.79(37.24)$ & 0.452 \\
\hline \multirow{6}{*}{ Mental health } & Bodily pain & $61.31(26.94)$ & $58.67(26.93)$ & $64.43(26.69)$ & 0.026 \\
\hline & General health & $60.41(15.56)$ & $59.45(15.67)$ & $61.55(15.38)$ & 0.164 \\
\hline & Vitality & $54.93(18.33)$ & $53.57(18.92)$ & $56.53(17.53)$ & 0.095 \\
\hline & Social functioning & $65.24(23.10)$ & $64.36(22.63)$ & $66.29(23.65)$ & 0.386 \\
\hline & Role emotional & $49.61(39.26)$ & $49.64(40.57)$ & $49.56(37.75)$ & 0.098 \\
\hline & Mental health & $58.67(19.70)$ & $58.59(21.01)$ & 58.78 (18.09) & 0.092 \\
\hline
\end{tabular}




\begin{tabular}{|c|c|c|c|c|c|}
\hline \multirow[t]{2}{*}{ Main domains } & \multirow[t]{2}{*}{ Subscales } & \multicolumn{3}{|c|}{ Poverty status } & \multirow[t]{2}{*}{ P-value } \\
\hline & & $\begin{array}{l}\text { High poverty } \\
\text { level }\end{array}$ & $\begin{array}{c}\text { Moderate } \\
\text { poverty level }\end{array}$ & $\begin{array}{c}\text { Low poverty } \\
\text { level }\end{array}$ & \\
\hline \multirow{4}{*}{ Physical health } & & Mean (SD) & Mean (SD) & Mean (SD) & \\
\hline & Physical functioning & $72.45(25.30)$ & $79.47(22.20)$ & $76.57(26.10)$ & 0.055 \\
\hline & Role physical & $54.92(39.22)$ & $60.09(35.81)$ & $59.83(35.49)$ & 0.414 \\
\hline & Bodily pain & $62.48(25.94)$ & $60.01(27.46)$ & $61.49(27.47)$ & 0.737 \\
\hline \multirow{5}{*}{ Mental health } & General health & $59.71(15.28)$ & $60.73(14.90)$ & $60.76(16.51)$ & 0.813 \\
\hline & Vitality & $54.62(19.29)$ & $55.17(17.38)$ & $54.98(18.45)$ & 0.968 \\
\hline & Social functioning & $66.37(21.78)$ & $64.96(22.80)$ & $64.45(24.67)$ & 0.769 \\
\hline & Role emotional & $49.52(40.86)$ & $49.87(37.98)$ & $49.42(39.22)$ & 0.995 \\
\hline & Mental health & $58.59(20.89)$ & $58.72(18.67)$ & $58.71(19.69)$ & 0.998 \\
\hline
\end{tabular}

Two backward linear regression analyses were conducted in which the physical and mental health domains of SF-36 were the dependent variables and perception of family socioeconomic status, age, sex, marital status, education and having a chronic illness were the independent variables. Having a chronic illness, perception of family socioeconomic status, age and sex predicted the physical health domain, whereas only perception of family socioeconomic status and having a chronic illness predicted the mental health domain (Table 5). As shown in Table 5 , the adjusted $\mathrm{R} 2$ for physical and mental health domains of health-related quality of life were 0.189 and 0.121 respectively. This means that $18.9 \%$ of the variation in the physical health domain can be explained by changes in the chronic disease, perception of family socioeconomic status, age and sex variables, and $12.1 \%$ of the variation in the mental health domain can be explained by changes in the perception of family socioeconomic status and chronic disease variables.

\section{Discussion}

We found no statistically significant differences between SF-36 health-related quality of life scores of the different poverty groups (high, middle and low poverty level). This finding differs from other studies that found a signifi- cant relationship between poverty and health $(12,16,19,20)$. For example Tampubolon and Hanandita (2014) found that higher levels of poverty were associated with more mental health problems (20). This difference in findings may be because the previous studies compared the health status of poor and non-poor people, while we compared poor people categorized into three poverty levels. Furthermore, our poverty measurement was based on a capability approach using factors such as literacy and not only income-based factors. This approach considers poverty not just income shortage but defines it as deprivation of individual and social capabilities (21). A poor person is someone who has no or a low power of choice, and it is the individual capabilities of a person as well as environmental capabilities that can give him/her power (21). This difference between our approach to poverty measurement and that of the previous studies is another possible explanation for the difference in results. Nonetheless, similar to our findings, other studies have also not found an association between poverty and health $(31,32)$.

We found a significant positive correlation between an individual's perception of their family socioeconomic status and health-related quality of life scores; people who had more positive perception of their family socioeconomic status had higher health-related quality

\begin{tabular}{|c|c|c|c|c|c|c|c|}
\hline \multicolumn{2}{|l|}{ Main domains } & \multirow{2}{*}{$\begin{array}{c}\text { B } \\
63.53\end{array}$} & \multirow{2}{*}{$\begin{array}{c}\text { Beta } \\
-\end{array}$} & \multirow{2}{*}{$\begin{array}{c}\text { SE } \\
3.260\end{array}$} & \multirow{2}{*}{$\begin{array}{c}\mathbf{t} \\
19.49\end{array}$} & \multirow[t]{2}{*}{ Adjusted $\mathbf{R}^{2}$} & \multirow{2}{*}{$\begin{array}{c}\text { P-value } \\
<0.001\end{array}$} \\
\hline Physical health $^{a}$ & Constant & & & & & & \\
\hline & Chronic disease & -14.38 & -0.285 & 2.47 & -5.82 & & $<0.001$ \\
\hline & Perception of family SES & 1.90 & 0.179 & 0.486 & 3.91 & 0.189 & $<0.001$ \\
\hline & Age & -0.229 & -0.133 & 0.083 & 2.76 & & 0.006 \\
\hline & Sex & 5.37 & 0.135 & 1.77 & 3.01 & & 0.003 \\
\hline \multirow[t]{3}{*}{ Mental health ${ }^{b}$} & Constant & 48.25 & - & 2.30 & 20.96 & & $<0.001$ \\
\hline & Perception of family SES & 2.70 & 0.252 & 0.511 & 5.29 & 0.121 & $<0.001$ \\
\hline & Chronic disease & -10.23 & -0.201 & 2.42 & -4.22 & & $<0.001$ \\
\hline
\end{tabular}

$S E=$ standard error,$S E S=$ socioeconomic status.

${ }^{a} R=0.444, R^{2}=0.197$.

${ }^{b} R=0.354, R^{2}=0.126$. 
of life scores. Similarly, in other studies, subjective socioeconomic status was associated with better physical and mental health, often more strongly than objective measures $(27,33,34)$.

Based on our data, the perception of the high poverty level group of their family socioeconomic status was significantly more positive than other groups. In the other words, the low poverty level group gave lower scores for their family socioeconomic status. Based on the capability approach, a person's living environment can or cannot give power of choice to people and this power has an influence on his/her actual poverty status (35). Accordingly, this finding suggests that the low poverty level group have a greater desire for a higher standard of living; therefore, living in marginalized neighbourhoods with fewer facilities and many environmental problems creates a sense of dissatisfaction about one's socioeconomic status. On the other hand, members of the high poverty level group, because they have lower expectations about standard of living, have less conflict with their living environment and its deprivations; therefore their expectations for a desired life are low and this leads to a more positive perception of their status in life. It may be that the poorer class has a limited conception and perceptual map of their environment because of their socioeconomic roots (25), and this leads to different impressions about the environment, even in poor neighbourhoods.

The mean score of the physical and mental dimensions of health-related quality of life of our respondents were 64.07 and 57.11 respectively. In contrast, the study of Rajabi-Gilan et al. (2014) in a sample of Iranian women living in informal settlements of Kermanshah city, using the WHO quality of life-BREF questionnaire, reported lower scores in these two dimensions (55.6 and 48.7 respectively) (36). This difference is probably a result of the different study tools used. The study of Ghafari et al. (2013) in the general population of Qom city, Islamic Republic of Iran reported similar findings to ours (37). We found no significant difference between the health-related quality of life mean scores of males and females except for the bodily pain subscale. The study of Ghafari et al. also found no sex differences except in the physical performance subscale, which is consistent with our findings (37).

Age was negatively associated with the subscales of the physical health domain of health-related quality of life, which is similar to the findings of Rajabi-Gilan et al. for female residents of informal settlements in Kermanshah city (36). However, in the mental health domain, only the vitality subscale was significantly associated with age, which is inconsistent with the findings of Rajabi-Gilan et al. (36).

The results of the regression analyses indicated that having a chronic illness, perception of family socioeconomic status, sex and age explained $18.4 \%$ of the health-related quality of life of respondents. Similarly, in the study of Ghasemi et al. among rural women in Kermanshah city, having a chronic illness was associated with and explained quality of life changes (7). These results indicate that medical interventions and improvements in quality of life are needed for residents of Kermanshah city informal settlements.

A limitation of our study was to calculate poverty without measuring income directly, even though it was addressed indirectly with other variables. However, assessing income variables directly using open or closed questions is not very valid and usually it is not possible to get reliable answers from respondents (38).

Eradication of poverty is the ultimate goal for policy-makers around the world, but it is out of reach in most societies. Because poverty is an important social determinant of health, reducing the effects of poverty on health, especially in poor neighbourhoods, is a health policy priority. The perception of individuals of their family socioeconomic status was strongly associated with their health-related quality of life in our study. Therefore, as a step towards reducing the effects of poverty on health, policy-makers should work on controlling the factors that affect people's perception of family socioeconomic status in poor neighbourhoods.

\section{Conclusion}

Based on the results of our study, the subjective perception of socioeconomic status partly explains health-related quality of life among poor people. Therefore, positive perceptions may control some of the negative effects of poverty on health-related quality of life . Therefore, in order to try and reduce the effect of poverty on health, it may be worthwhile and less difficult for policy-makers to consider trying to influence subjective perceptions of socioeconomic status rather than objective poverty.

\section{Acknowledgements}

We thank our colleagues working in the Social Development and Health Promotion Research Centre, Kermanshah University of Medical Sciences.

Funding: This study was funded by Kermanshah University of Medical Sciences, Kermanshah, Islamic Republic of Iran (grant number 93493).

Competing interests: None declared. 


\section{Qualité de vie liée à la santé dans les quartiers informels de Kermanshah (République islamique d'Iran) : rôle de la pauvreté et perception du statut socio-économique de la famille}

\section{Résumé}

Contexte : La qualité de vie est un indicateur important pour mesurer l'état de santé et les informations sur la qualité de vie de différents groupes de la société peuvent être utilisées pour évaluer l'effet des interventions sur la santé.

Objectifs : La présente étude visait à évaluer la relation entre la pauvreté urbaine et la perception du statut socioéconomique de la famille et la qualité de vie liée à la santé des résidents des quartiers informels.

Méthodes : Une étude transversale a été menée auprès de 432 résidents de deux quartiers informels à Kermanshah en 2015. Pour mesurer la pauvreté, les 16 indicateurs du recensement iranien de 2011 ont été utilisés. Les quartiers ont été classés en trois groupes : pauvreté élevée (9,3\%), moyenne (49,2\%) et faible (41,5\%). La qualité de vie liée à la santé a été évaluée à l'aide du questionnaire SF-36. Le coefficient de corrélation de Pearson a été calculé et des analyses de régression et de la variance ont été effectuées.

Résultats : Aucune différence statistiquement significative entre les scores du SF-36 pour les trois niveaux de pauvreté et aucune relation entre la pauvreté et les sous-échelles de qualité de vie liée à la santé n'ont été établies $(p>0,05)$. Une corrélation positive significative a été observée entre la perception du statut socio-économique de la famille et la qualité de vie liée à la santé $(p<0,05)$. À l'analyse de régression, le fait d'être atteint d'une maladie chronique, la perception du statut socio-économique de la famille, l'âge et le sexe permettent de prédire le score du domaine de la santé physique du SF-36, tandis que la perception du statut socio-économique de la famille et le fait d'être atteint d'une maladie chronique permettent de prédire le score du domaine de la santé mentale.

Conclusions : La perception subjective du statut socio-économique de la famille peut expliquer les différences de qualité de vie liées à la santé chez les personnes à faible revenu.

$$
\begin{aligned}
& \text { جودة الحياة الصحية في الأحياء العشوائية في كرمانشاه، بجمهورية إيران الإسلامية: دور الفقر وتصور الحالة } \\
& \text { الاجتماعية الاقتصادية للأسرة } \\
& \text { سيد رامين قاسمي، علي رضا زنجنة، نادر رجبي -جيلان، سهيلة رشادات، شهرام سعيدي، آرش ضيابور }
\end{aligned}
$$

الخلفية: تعدّ جودة الحياة مؤشراً مهاًً لقياس الحالة الصحية، ويمكن استخدام المعلومات الخاصة بجودة حياة شتى فئات المجتمع لتقيم تأثير التدخلات على الصحة.

الأهداف: هدفت هذه الدراسة إلى تقييم العلاقة بين الفقر في المناطق الحضرية وتصور الحالة الاجتحاعية الاقتصادية للأسرة من ناحية، وجودة الحياة

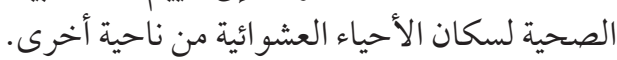

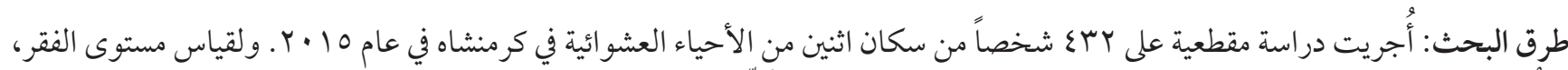

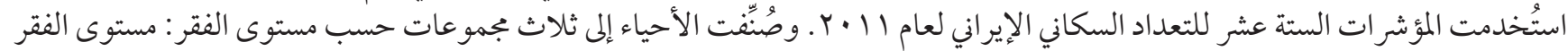

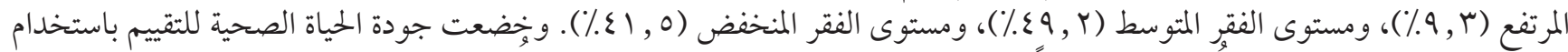

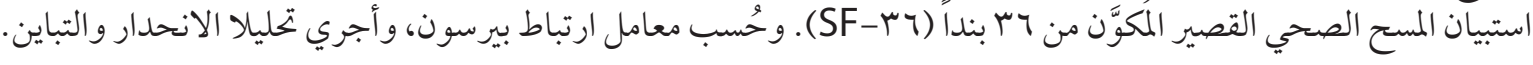

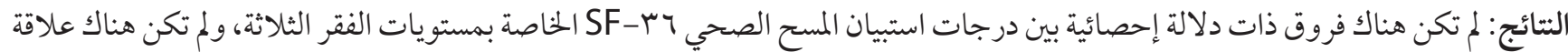

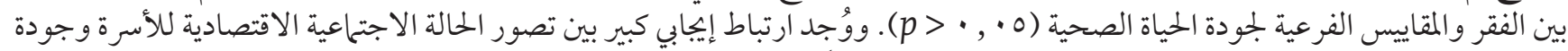

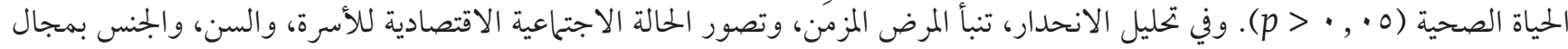

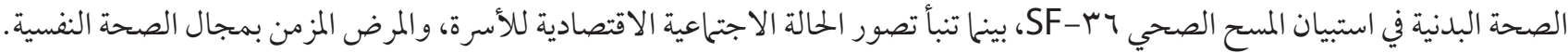
الاستنتاجات: يمكن أن يقدم التصور الذاتي للحالة الاجتماعية الاقتصادية للأسرة تفسيراً للفروق الموجودة في جودة حياة الفقراء الصحية. 


\section{References}

1. Bache I. Measuring quality of life for public policy: an idea whose time has come? Agenda-setting dynamics in the European Union. J European Public Policy. 2013;20(1):21-38.

2. Rajabi-Gilan N., Ghasemi SR., Reshadat S., Rajabi S. The relationship between social capital and health-related quality of life among teachers. J Zanjan Univ Med Sci. 2013;21(88):95-107.

3. Mirghafourvand M, Charandabi SM-A, Jafarabadi MA, Tavananezhad N, Karkhane M. Predictors of health-related quality of life in Iranian women of reproductive age. Applied Res Quality Life. 2016;11(3):723-37.

4. Pourtaheri M., Eftekhari A., Fatahi A. Assessment quality of life (QOL) in rural areas (Case study: Northern Khaveh village, Lorestan province). Human Geog Res. 2011;43(76):13-31.

5. Theofilou P. Quality of life: definition and measurement. Eur J Psychol. 2013;9(1):150-62.

6. World Health Organization. Health statistics and information systems. WHOQOL: measuring quality of life (https://www.who. int/healthinfo/survey/whoqol-qualityoflife/en/,accesses 17 February 2019).

7. Ghasemi SR., Rjabi Gilan N., Reshadat S. The survey of health-related quality of life in Kermanshah rural women and some related factors. J Mazandaran Univ Med Sci. 2014;24(109):186-94.

8. UN-HABITAT. State of the world's cities 2010/2011: bridging the urban divide. London: Earthscan; 2010.

9. Analytical perspective of pro-poor slum upgrading frameworks. Nairobi: UN-HABITAT; 2006.

10. Irandoost K, Azami M, Tavallaei R. Defining indicators of informal settlements in Iran. J Urban-Regional Studies Res. 2014;6(21):43-60.

11. UN-HABITAT. State of the world's cities. The Millennium Development Goals and urban sustainability. London: Earthscan; 2006.

12. UN-Habitat. The challenge of slums: global report on human settlements 2003. Management of Environmental Quality: An International Journal. 2004;15(3):337-8.

13. Tilaki MJM, Justafa RA, Marzbali MH, Abdullah A, Ariffin J. Challenges of the informal settlements in developing countries' cities: a case study of Iran. World Applied Sci J. 2001;12:160-9.

14. Statistical Center of Iran. Population and housing censuses; 2016 (https://www.amar.org.ir/english/Population-and-Housing-Censuses, accessed 17 February 2019).

15. Rustaee SH, Ahadnejad M, Asgharizamani A, Zangeneh A, Saeedi SH. Evaluation of urban poverty in informal settlements across Kermanshah, Iran through factor analysis (a case study of Dolat Abad \& Shater Abad Settlements in 2006). J. Geog Plan. 2015;19(53):137-66.

16. Zangane Shahraki S, Sharifdini JG, Hassanzadeh D, Salary Moghadam Z. Evaluation of the quality of life in informal settlements, Tehran metropolitan (case study: Islamabad Salehabad). Human Geog Res. 2014;46(1):177-96.

17. Roustaei S, Ahadnezhad M, Zamani AA, Zangene A. The comparative pattern of poverty spread in Kermanshah City in 1996-2006 using factor analysis technique. Urban-Regional Studies and Research (University Of Isfahan). 2012;3(12):5-8.

18. Adena M, Myck M. Poverty and transitions in health in later life. Soc Sci Med. 2014;116:202-10.

19. Raphael D. Poverty in childhood and adverse health outcomes in adulthood. Maturitas. 2011;69(1):22-6.

20. Tampubolon G., Hanandita W. Poverty and mental health in Indonesia. Soc Sci Med. 2014;106:20-7.

21. Heidarnia MA, Ghaemian T, Abadi A, Fathian S, Montazeri A. Health-related quality of life and poverty. Payesh. 2012;11(4):491-5.

22. Sen A. Inequality reexamined. New York: Clarendon Press; 1992.

23. Robeyns I. Capabilitarianism. J Human Develop Capabilities. 2016;17(3):397-414.

24. Reshadat S, Zangeneh A, Saeidi S, Khademi N, Izadi N, Ghasemi SR, et al. The spatial clustering analysis of HIV and poverty through GIS in the metropolis of Kermanshah, western Iran. Acta Medica Mediterranea. 2016;32:1995-9.

25. Harvey D. Social justice and the city. Atlanta: University of Georgia Press; 2010.

26. Weeks JR, Getis A, Hill AG, Agyei-Mensah S, Rain D. Neighborhoods and fertility in Accra, Ghana: An AMOEBA-based approach. Ann Assoc Am Geogr. 2010;100(3):558-78.

27. Operario D, Adler NE, Williams DR. Subjective social status: reliability and predictive utility for global health. Psychology \& Health. 2004;19(2):237-46.

28. Odéen M, Westerlund H, Theorell T, Leineweber C, Eriksen HR, Ursin H. Expectancies, socioeconomic status, and self-rated health: use of the simplified TOMCATS questionnaire. Int J Behav Med. 2013;20(2):242-51.

29. Ware JE, Gandek B. Overview of the SF-36 health survey and the international quality of life assessment (IQOLA) project. J Clin Epidemiol. 1998;51(11):903-12.

30. Montazeri A., Goshtasebi A., Vahdaninia M. Translating, reliability and validity of Persian form of SF-36 standard tool. Payesh. 2005;5(1):49-56.

31. Das J, Do Q-T, Friedman J, McKenzie D, Scott K. Mental health and poverty in developing countries: Revisiting the relationship. Soc Sci Med. 2007;65(3):467-80. 
32. Das J, Do Q-T, Friedman J, McKenzie D. Mental health patterns and consequences: results from survey data in five developing countries. The World Bank Economic Review. 2008;23(1):31-55.

33. Miyakawa M, Magnusson Hanson LL, Theorell T, Westerlund H. Subjective social status: its determinants and association with health in the Swedish working population (the SLOSH study). Eur J Public Health. 2011;22(4):593-7.

34. Singh-Manoux A, Adler NE, Marmot MG. Subjective social status: its determinants and its association with measures of illhealth in the Whitehall II study. Soc Sci Med. 2003;56(6):1321-33.

35. Mahmoudi V, Samimifar G. Poverty as capability deprivation. Social Welfare Quarterly. 2005;17(5):9-32.

36. Rajabi-Gilan N, Ghasemi S, Reshadat S, Zanganeh A, Saeidi S. Health-related quality of life of women in marginal areas of Kermanshah and some related factors. J Kermanshah Univ Med Sci. 2014;18(9):547-56.

37. Ghafari R., Rafiei M., Taheri-Nejad MR. Assessment of health related quality of life by SF-36 Version 2 in general population of Qom city. Arak Med Univ J. 2014;16(80):62-71.

38. Sahn DE, Stifel D. Exploring alternative measures of welfare in the absence of expenditure data. Review of income and wealth. 2003;49(4):463-89. 